\title{
Association of common genetic variants with brain microbleeds
}

\author{
A genome-wide association study
}

Maria J. Knol, BSc, * Dongwei Lu, MD, PhD,* Matthew Traylor, PhD, * Hieab H.H. Adams, MD, PhD,* José Rafael J. Romero, MD, Albert V. Smith, PhD, Myriam Fornage, PhD, Edith Hofer, PhD, Junfeng Liu, MD, PhD, Isabel C. Hostettler, MD, Michelle Luciano, PhD, Stella Trompet, PhD, Anne-Katrin Giese, MD, Saima Hilal, MD, PhD, Erik B. van den Akker, PhD, Dina Vojinovic, MD, PhD, Shuo Li, PhD, Sigurdur Sigurdsson, MSc, Sven J. van der Lee, MD, PhD, Clifford R. Jack, Jr., MD, Duncan Wilson, PhD, Pinar Yilmaz, MD, Claudia L. Satizabal, PhD, David C.M. Liewald, BSc, Jeroen van der Grond, PhD, Christopher Chen, FRCP, Yasaman Saba, MSc, Aad van der Lugt, MD, PhD, Mark E. Bastin, DPhil, B. Gwen Windham, MD, MHS, Ching Yu Cheng, MD, PhD, Lukas Pirpamer, MSc, Kejal Kantarci, MD, Jayandra J. Himali, PhD, Qiong Yang, PhD, Zoe Morris, MD, Alexa S. Beiser, PhD, Daniel J. Tozer, PhD, Meike W. Vernooij, MD, PhD, Najaf Amin, PhD, Marian Beekman, PhD, Jia Yu Koh, PhD, David J. Stott, MD, Henry Houlden, PhD, Reinhold Schmidt, MD, Rebecca F. Gottesman, MD, PhD, Andrew D. MacKinnon, MD, Charles DeCarli, MD, Vilmundur Gudnason, MD, PhD, lan J. Deary, PhD, Cornelia M. van Duijn, PhD, P. Eline Slagboom, PhD, Tien Yin Wong, MD, PhD, Natalia S. Rost, MD, MPH, J. Wouter Jukema, PhD, Thomas H. Mosley, PhD, David J. Werring, PhD, Helena Schmidt, MD, PhD, Joanna M. Wardlaw, MD, M. Arfan Ikram, MD, PhD, † Sudha Seshadri, MD, † Lenore J. Launer, PhD, † and Hugh S. Markus, DM, FMed Sci, $†$ for the Alzheimer's Disease Neuroimaging Initiative

Neurology ${ }^{\circledR}$ 2020;95:e3331-e3343. doi:10.1212/WNL.0000000000010852

\author{
Correspondence \\ Dr. Launer \\ launerl@nia.nih.gov \\ or Dr. Markus \\ hsm32@medschl.cam.ac.uk
}

\begin{abstract}
Objective

To identify common genetic variants associated with the presence of brain microbleeds (BMBs).

\section{Methods}

We performed genome-wide association studies in 11 population-based cohort studies and 3 case-control or case-only stroke cohorts. Genotypes were imputed to the Haplotype Reference
\end{abstract}

\begin{abstract}
*These authors contributed equally to this work.
tThese authors jointly directed the work.

From the Departments of Epidemiology (M.J.K., H.H.H.A., D.V., S.J.v.d.L., P.Y., M.W.V., N.A., C.M.v.D., M.A.I.), Radiology and Nuclear Medicine (H.H.H.A., P.Y., A.v.d.L., M.W.V.), and Clinical Genetics (H.H.H.A.), Erasmus MC University Medical Center, Rotterdam, the Netherlands; Stroke Research Group, Department of Clinical Neurosciences (D.L., M.T., J.L., D.J.T., H.S.M.), University of Cambridge, UK; Department of Neurology (J.R.J.R., C.L.S., J.J.H., A.S.B., C.D., S. Seshadri), Boston University School of Medicine; The Framingham Heart Study (J.R.J.R., C.L.S., J.J.H., A.S.B., S. Seshadri), MA; Department of Biostatistics (A.V.S.), University of Michigan, Ann Arbor; Icelandic Heart Association (A.V.S., S. Sigurdsson, V.G.), Kopavogur, Iceland; Brown Foundation Institute of Molecular Medicine, McGovern Medical School (M.F.), and Human Genetics Center, School of Public Health (M.F.), University of Texas Health Science Center at Houston; Clinical Division of Neurogeriatrics, Department of Neurology (E.H., L.P., R.S.), Institute for Medical Informatics, Statistics and Documentation (E.H.), and Gottfried Schatz Research Center, Department of Molecular Biology and Biochemistry (Y.S., H.S.), Medical University of Graz, Austria; Center of Cerebrovascular Diseases, Department of Neurology (J.L.), West China Hospital, Sichuan University, Chengdu; Stroke Research Centre, Queen Square Institute of Neurology (I.C.H., D.W., H.H., D.J.W.), University College London, UK; Department of Neurosurgery (I.C.H.), Klinikum rechts der Isar, University of Munich, Germany; Centre for Cognitive Ageing and Cognitive Epidemiology, Psychology (M.L., D.C.M.L., M.E.B., I.J.D., J.M.W.), and Centre for Clinical Brain Sciences, Edinburgh Imaging, UK Dementia Research Institute (M.E.B., J.M.W.), University of Edinburgh, UK; Department of Internal Medicine, Section of Gerontology and Geriatrics (S.T.), Department of Cardiology (S.T., J.v.d.G., J.W.J.), Section of Molecular Epidemiology, Biomedical Data Sciences (E.B.v.d.A., M.B., P.E.S.), Leiden Computational Biology Center, Biomedical Data Sciences (E.B.v.d.A.), Department of Radiology (..v.d.G.), and Einthoven Laboratory for Experimental Vascular Medicine (J.W.J.), Leiden University Medical Center, the Netherlands; Department of Neurology (A.-K.G., N.S.R.), Massachusetts General Hospital, Harvard Medical School, Boston; Memory Aging and Cognition Center (S.H., C.C.), National University Health System, Singapore; Department of Pharmacology (S.H., C.C.) and Saw Swee Hock School of Public Health (S.H.), National University of Singapore and National University Health System, Singapore; Pattern Recognition \& Bioinformatics (E.B.v.d.A.), Delft University of Technology, the Netherlands; Department of Biostatistics (S.L., J.J.H., Q.Y., A.S.B.), Boston University School of Public Health, MA; Department of Radiology (C.R.J., K.K.), Mayo Clinic, Rochester, MN; Glenn Biggs Institute for Alzheimer's \& Neurodegenerative Diseases (C.L.S., S. Seshadri), UT Health San Antonio, TX; Department of Medicine, Division of Geriatrics (B.G.W., T.H.M), and Memory Impairment and Neurodegenerative Dementia (MIND) Center (T.H.M.), University of Mississippi Medical Center, Jackson; Singapore Eye Research Institute (C.Y.C., J.Y.K., T.Y.W.); Department of Neuroradiology (Z.M., J.M.W.), NHS Lothian, Edinburgh; Institute of Cardiovascular and Medical Sciences (D.J.S.), College of Medical, Veterinary and Life Sciences, University of Glasgow, UK; Division of Cerebrovascular Neurology (R.F.G.), Johns Hopkins University, Baltimore, MD; Department of Neuroradiology (A.D.M.), Atkinson Morley Neurosciences Centre, St George's NHS Foundation Trust, London, UK; Department of Neurology (C.D.), University of California at Davis; Nuffield Department of Population Health (C.M.v.D.), University of Oxford, UK; Laboratory of Epidemiology and Population Sciences (L.J.L.), National Institute on Aging, Baltimore, MD; and Faculty of Medicine (V.G.), University of Iceland, Reykjavik, Iceland.

Data used in preparation of this article were obtained from the Alzheimer's Disease Neuroimaging Initiative (ADNI) database (adni.loni.usc.edu). As such, the investigators within the ADNI contributed to the design and implementation of ADNI and/or provided data but did not participate in analysis or writing of this report. A complete listing of ADNI investigators
\end{abstract} can be found in the coinvestigators list at links.Iww.com/WNL/B222.

Go to Neurology.org/N for full disclosures. Funding information and disclosures deemed relevant by the authors, if any, are provided at the end of the article.

This is an open access article distributed under the terms of the Creative Commons Attribution-NonCommercial-NoDerivatives License 4.0 (CC BY-NC-ND), which permits downloading and sharing the work provided it is properly cited. The work cannot be changed in any way or used commercially without permission from the journal. 


\section{Glossary}

$\mathrm{AD}=$ Alzheimer disease; CHARGE $=$ Cohorts of Heart and Aging Research in Genomic Epidemiology; $\mathbf{C I}=$ confidence interval; CSVD = cerebral small vessel disease; $\mathbf{B M B}=$ brain microbleed; GWAS = genome-wide association studies; $\mathbf{I C H}=$ intracerebral hemorrhage; $\mathbf{L D}=$ linkage disequilibrium; $\mathrm{MAF}=$ minor allele frequency; $\mathrm{OR}=$ odds ratio; $\mathrm{SNP}=$ single nucleotide polymorphism; SWI = susceptibility-weighted imaging; WMH = white matter hyperintensities.

Consortium or 1000 Genomes reference panel. BMBs were rated on susceptibility-weighted or

$\mathrm{T} 22^{*}$-weighted gradient echo MRI sequences, and further classified as lobar or mixed (including strictly deep and infratentorial, possibly with lobar BMB). In a subset, we assessed the effects of APOE $\varepsilon 2$ and $\varepsilon 4$ alleles on BMB counts. We also related previously identified cerebral small vessel disease variants to BMBs.

\section{Results}

BMBs were detected in 3,556 of the 25,862 participants, of which 2,179 were strictly lobar and 1,293 mixed. One locus in the APOE region reached genome-wide significance for its association with BMB (lead single nucleotide polymorphism rs769449; odds ratio $[\mathrm{OR}]_{\text {any } B M B}[95 \%$ confidence interval $\left.(\mathrm{CI})] 1.33[1.21-1.45] ; p=2.5 \times 10^{-10}\right)$. APOE $\varepsilon 4$ alleles were associated with strictly lobar (OR [95\% CI] $1.34[1.19-1.50] ; p=1.0 \times 10^{-6}$ ) but not with mixed BMB counts (OR [95\% CI] $\left.1.04[0.86-1.25] ; p=0.68\right)$. $A P O E \varepsilon 2$ alleles did not show associations with BMB counts. Variants previously related to deep intracerebral hemorrhage and lacunar stroke, and a risk score of cerebral white matter hyperintensity variants, were associated with BMB.

\section{Conclusions}

Genetic variants in the $A P O E$ region are associated with the presence of $\mathrm{BMB}$, most likely due to the APOE $\varepsilon 4$ allele count related to a higher number of strictly lobar BMBs. Genetic predisposition to small vessel disease confers risk of BMB, indicating genetic overlap with other cerebral small vessel disease markers.

Brain microbleeds (BMBs), also referred to as cerebral microbleeds or cerebral microhemorrhages, correspond to hemosiderin deposits as a result of microscopic hemorrhages that are visible on MRI sequences. ${ }^{1}$ The frequency of BMBs increases with age and with certain pathologies, including cerebral small vessel disease (CSVD), ${ }^{2}$ and in prospective studies $\mathrm{BMB}$ can predict risk of ischemic stroke and intracerebral hemorrhage (ICH) ${ }^{3,4}$ It has been suggested BMB may represent a marker that can stratify risk, particularly risk of $\mathrm{ICH}$, in patients taking antithrombotic and anticoagulant therapy. ${ }^{5}$

Microbleeds can occur in the cortical area or the corticosubcortical border (lobar) and the subcortical (deep) structures of the brain. BMBs in lobar regions are often seen in both familial and sporadic cerebral amyloid angiopathy, whereas deep BMBs are more common in sporadic deep perforator arteriopathy. ${ }^{6-8}$ This suggests that different pathophysiologic mechanisms may underlie BMBs in the 2 locations, a situation similar to that of $\mathrm{ICH}$, where the genetic risk factor profiles for lobar and deep hemorrhage have been shown to differ. ${ }^{9}$

BMBs represent one of a spectrum of MRI markers of CSVD, with others including white matter hyperintensities (WMH) and lacunar infarcts. ${ }^{1}$ Genome-wide association studies (GWAS) of these other markers, particularly WMH, have provided novel insights into the underlying disease mechanisms. ${ }^{10,11}$ However, much less is known of the genetic basis of BMB. ${ }^{12,13}$ We hypothesized that common genetic variants contribute to interindividual variation in
$\mathrm{BMB}$. Therefore, we performed the largest GWAS on BMB to date to evaluate this. In addition to any $\mathrm{BMB}$, we performed separate GWAS for lobar BMB and mixed BMB.

\section{Methods}

\section{Study population}

The study included data from 2 large initiatives: the Cohorts of Heart and Aging Research in Genomic Epidemiology (CHARGE) consortium ${ }^{14}$ and the UK Biobank (ukbiobank.ac.uk), combined with additional data from the case-control Alzheimer's Disease Neuroimaging Initiative (ADNI) database (adni.loni.usc.edu) and the Massachusetts General Hospital Genes Affecting Stroke Risk and Outcomes Study (MGH-GASROS) ${ }^{15}$ and Clinical Relevance of Microbleeds in Stroke due to Atrial Fibrillation (CROMIS-2 AF) ${ }^{4}$ stroke studies. Together this comprised 25,862 individuals from 9 population-based and 2 family-based cohort studies, as well as 1 case-control study and 2 case-only cohorts (table 1 ).

\section{Standard protocol approvals, registrations, and patient consents}

The individual studies have been approved by their local institutional review boards or ethics committees. Written informed consent was obtained from all individuals participating in the study. 


\begin{tabular}{|c|c|c|c|c|c|c|c|c|c|c|c|}
\hline Study & Study design & Ancestry & Total & Any BMBs & Lobar BMBs & Mixed BMBs & Female & Age, y & Age range, $y$ & Dementia & Stroke \\
\hline ADNI & $\begin{array}{l}\text { Case-control (AD, MCl, } \\
\text { healthy controls) }\end{array}$ & European & 734 & 149 & 95 & 54 & $330(45.0)$ & $73.1 \pm 7.5$ & $48-94$ & 116 & 45 \\
\hline AGES & Population-based & European & 2,894 & 469 & 272 & 197 & $1,679(58.0)$ & $76.4 \pm 5.5$ & $66-95$ & 149 & 223 \\
\hline ASPS & Population-based & European & 203 & 34 & NA & 28 & $89(43.8)$ & $60.1 \pm 6.3$ & $46-79$ & 0 & 0 \\
\hline ARIC (AA) & Population-based & European & 422 & 118 & 81 & 31 & $281(66.6)$ & $75.4 \pm 5.1$ & $67-89$ & 24 & 22 \\
\hline ARIC (EA) & Population-based & African American & 1,174 & 267 & 184 & 74 & $680(57.9)$ & $77.0 \pm 5.3$ & $67-90$ & 70 & 34 \\
\hline CROMIS-2 AF & Case-only (stroke cases) & European & 1,238 & 253 & 94 & 158 & $522(42.2)$ & $75.1 \pm 12.6$ & $35-100$ & 32 & 1,238 \\
\hline EDIS-SCES & Population-based & Chinese & 130 & 42 & 27 & NA & $69(53.1)$ & $70.5 \pm 6.1$ & $60-85$ & 5 & 6 \\
\hline EDIS-SiMES & Population-based & Malay & 204 & 75 & 36 & NA & $107(52.5)$ & $70.6 \pm 6.6$ & $60-85$ & 21 & 8 \\
\hline ERF & Family-based & European & 126 & 27 & 15 & 12 & $66(52.4)$ & $64.5 \pm 4.6$ & $55-75$ & 0 & 0 \\
\hline FHS & Population-based & European & 3,968 & 257 & 176 & 81 & $2,115(53.3)$ & $57.3 \pm 13.6$ & $25-96$ & 25 & 51 \\
\hline LBC1936 & Population-based & European & 626 & 74 & 21 & 53 & $295(47.1)$ & $72.7 \pm 0.7$ & $71-74$ & 5 & 43 \\
\hline LLS & Family-based & European & 279 & 39 & 24 & 11 & $147(52.7)$ & $65.8 \pm 6.9$ & $45-84$ & 0 & 0 \\
\hline MGH-GASROS & Case-only (stroke cases) & European & 380 & 106 & 51 & 55 & $127(36.0)$ & $66.7 \pm 15.0$ & $18-102$ & 0 & 353 \\
\hline PROSPER & RCT/population-based & European & 456 & 104 & 74 & 26 & $197(43.2)$ & $75.0 \pm 3.2$ & $70-83$ & 0 & 74 \\
\hline RS1 & Population-based & European & 1,119 & 384 & 234 & 150 & $642(57.4)$ & $79.2 \pm 5.0$ & $68-96$ & 30 & 64 \\
\hline RS2 & Population-based & European & 1,206 & 270 & 167 & 103 & $628(52.1)$ & $69.7 \pm 6.2$ & $60-97$ & 8 & 23 \\
\hline RS3 & Population-based & European & 2,611 & 318 & 237 & 81 & $1,444(55.3)$ & $57.3 \pm 6.6$ & $45-89$ & 0 & 3 \\
\hline UK Biobank & Population-based & European & 8,092 & 570 & 391 & 179 & $4,263(52.7)$ & $62.1 \pm 7.4$ & $44-78$ & 3 & 75 \\
\hline \multicolumn{3}{|l|}{ Totals } & 25,862 & 3,556 & 2,179 & \multicolumn{6}{|l|}{1,293} \\
\hline \multicolumn{12}{|c|}{ 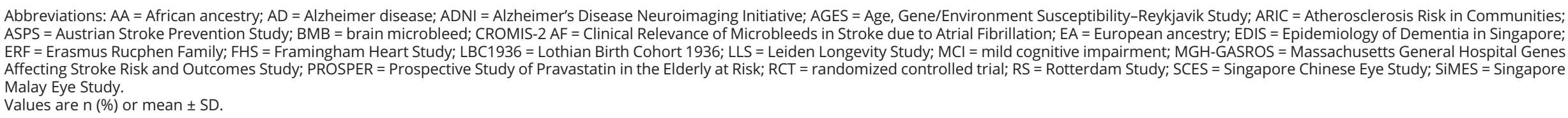 } \\
\hline
\end{tabular}




\section{Genotyping}

Genotyping was performed on commercially available assays from Illumina (San Diego, CA) or Affymetrix (Santa Clara, $\mathrm{CA}$ ) and were imputed using the Haplotype Reference Consortium or 1000 Genomes reference panels (supplementary table e-1, doi.org/10.5061/dryad.mcvdncjz4). Most cohorts included individuals of European ancestry only, but a subset of individuals with Chinese, Malay, or African American ancestry $(n=130, n=204$, and $n=422$, respectively) was also included.

\section{Assessment of brain microbleeds}

MRI scans with field strengths of $1 \mathrm{~T}, 1.5 \mathrm{~T}$, or $3 \mathrm{~T}$ and full brain coverage were acquired in each participating study (supplementary table e-2, doi.org/10.5061/dryad.mcvdncjz4). Definitions of BMB have been described previously. ${ }^{16}$ Briefly, BMBs can be recognized as small, hypointense lesions on susceptibilityweighted imaging (SWI) sequences or, to a lesser extent, on $\mathrm{T} 2^{*}$-weighted gradient echo sequences. Although BMB assessment using SWI sequences is more sensitive than assessment using $\mathrm{T}^{*}$-weighted sequences, ${ }^{17,18}$ the clinical relevance of this improved sensitivity is debated since it is also less specific. ${ }^{19}$ Because previous research has shown differences between risk factors and clinical correlates of BMBs in specific locations of the brain, ${ }^{6,8,20}$ we further differentiated between strictly lobar and deep infratentorial or mixed BMBs. Cases in which there were microbleeds located in cortical gray or subcortical white matter of the brain lobes without any microbleeds in deep or infratentorial regions were classified as lobar BMBs. Microbleeds in the deep gray matter of basal ganglia and thalamus or in brainstem or cerebellum were classified as deep or infratentorial BMBs. Due to the low number of cases of $\mathrm{BMB}$, especially the deep and infratentorial subtypes, we created one group of mixed $\mathrm{BMB}$ cases. Mixed BMB was defined as deep or infratentorial BMB, possibly in combination with microbleeds in lobar regions. In a minority of cohorts (table 1), the data on lobar or mixed BMB were not available, and therefore the total number of lobar and mixed BMBs is slightly less than the total number of BMBs. Studyspecific methodologies for the identification of BMBs have been described elsewhere. ${ }^{1,621-30}$ Because BMB assessment in the UK Biobank has not been described before, additional information regarding the UK Biobank sample, including microbleeds assessment, is provided in the supplementary information (doi.org/ 10.5061/dryad.mcvdncjz4).

\section{Genome-wide association studies}

In each participating study, genome-wide association analyses were performed using logistic regression under an additive model, adjusted for age, sex, and principal components of ancestry to account for population structure (if needed) and family relations (if applicable). For each study, variants were filtered by imputation quality using an INFO or $r^{2}$ above 0.5 , minor allele frequency (MAF) above 0.005 , and $\mathrm{MAF}^{*} \mathrm{~N}_{\text {case- }}$ ${ }_{s}^{*}$ imputation quality $>5$. Within the CHARGE consortium plus additional case-control and case-only studies, only variants available in at least 2 cohorts were analyzed. Then, genetic variants were filtered using MAF > 0.01, after which the
CHARGE consortium with additional studies and UK Biobank results were meta-analyzed together. An inverse varianceweighted fixed-effects model was applied in METAL using the standard error analysis scheme. ${ }^{31}$ As a sensitivity analysis, we performed this analysis while excluding individuals with dementia and stroke, to investigate whether the associations were driven by these diseases. To examine whether there was substantial genomic inflation due to population stratification, we inspected the linkage disequilibrium (LD) score regression intercept (supplementary table e-3, doi.org/10.5061/dryad. mcrdncjz4). ${ }^{32}$ For follow-up analyses, only variants present in more than half of the cases were included. HaploReg v4.1 was used for the functional annotation of the suggestive $(p<5 \times$ $\left.10^{-6}\right)$ and genome-wide significant $\left(p<5 \times 10^{-8}\right)$ variants, and variants in $\mathrm{LD}$ at a threshold of $r^{2}>0.8 .^{33}$

\section{APOE $\varepsilon 2$ and $\varepsilon 4$ count analysis}

In the 2 largest cohorts (i.e., UK Biobank and Rotterdam Study), we investigated the effect of $A P O E \varepsilon 2$ and $\varepsilon 4$ allele counts, directly genotyped using a polymerase chain reaction, inferred from imputed Haplotype Reference Consortium values of rs429358 and rs7412, or a combination of both. Zero-inflated negative binomial regression analysis was performed investigating the association of $A P O E$ allele counts with the number of any, lobar, and mixed BMB, adjusted for age, sex, and principal components. For each individual, we counted the number of $A P O E \varepsilon 2$ alleles ( $\varepsilon 2 \varepsilon 2$ coded as $2, \varepsilon 2 \varepsilon 3$ and $\varepsilon 2 \varepsilon 4$ as 1 , and $\varepsilon 3 \varepsilon 3$, $\varepsilon 3 \varepsilon 4$, and $\varepsilon 4 \varepsilon 4$ as 0$)$ and the number of APOE $\varepsilon 4$ alleles ( $\varepsilon 4 \varepsilon 4$ coded as 2 , $\varepsilon 2 \varepsilon 4$ and $\varepsilon 3 \varepsilon 4$ as 1 , and $\varepsilon 2 \varepsilon 2$, $\varepsilon 2 \varepsilon 3$, and $\varepsilon 3 \varepsilon 34$ as 0 ). We repeated these analyses while setting APOE $\varepsilon 2 \varepsilon 4$ values to missing since this combines the protective $\varepsilon 2$ and the riskincreasing $\varepsilon 4$ allele for Alzheimer disease $(\mathrm{AD})$ and may therefore dilute the effects. For these analyses, counts of more than 100 microbleeds were considered outliers and removed from the analysis ( $\mathrm{n}=2$ in the UK Biobank; $\mathrm{n}=2$ in the Rotterdam Study).

\section{Two-sample mendelian randomization}

In order to test potential causal effects of cardiovascular risk factors on BMBs, we performed a 2-sample mendelian randomization using an inverse variance-weighted method implemented in the MendelianRandomization $\mathrm{R}$ library. Summary statistic data of GWAS were acquired for the following traits: type 2 diabetes mellitus, ${ }^{34}$ systolic and diastolic blood pressure, pulse pressure, ${ }^{35}$ body mass index, ${ }^{36}$ lowdensity lipoprotein cholesterol, high-density lipoprotein cholesterol, and triglycerides. ${ }^{37}$

\section{Related phenotypes}

For independent $\left(r^{2} \leq 0.8\right)$ variants previously associated at genome-wide significance with other traits that in turn might be related to BMBs, we assessed the association with BMBs as well. First we examined variants associated with other manifestations of CSVD, namely WMH, ${ }^{10,11,15}$ lacunar stroke, ${ }^{38,39}$ and ICH. ${ }^{39,40}$ Second we examined associations with traits that have been shown to be predicted by $\mathrm{BMB}$, namely any stroke, any ischemic stroke, ${ }^{41,42}$ and $\mathrm{AD} .^{43}$ For each related phenotype, we corrected 
Table 2 Independent genetic variants significantly $\left(p<5 \times 10^{-8}\right)$ or suggestively $\left(p<1 \times 10^{-6}\right)$ associated with any or location-specific brain microbleeds (BMBs)

\begin{tabular}{|c|c|c|c|c|c|c|c|c|c|c|c|c|c|}
\hline SNP & Chr & Position & A1 & $\mathrm{A} 2$ & EAF & $\begin{array}{l}\text { Nearest } \\
\text { gene }\end{array}$ & Outcome & $\beta$ & SE & OR & Total & Cases & $p$ Value \\
\hline \multirow[t]{3}{*}{ rs769449 } & 19 & 45410002 & A & G & 0.13 & $A P O E$ & Any BMBs & 0.282 & 0.045 & 1.33 & 20,150 & 2,858 & $2.5 \times 10^{-10}$ \\
\hline & & & & & & & Lobar BMBs & 0.280 & 0.055 & 1.32 & 18,666 & 1,748 & $4.3 \times 10^{-7}$ \\
\hline & & & & & & & Mixed BMBs & 0.243 & 0.070 & 1.27 & 18,319 & 1,049 & $5.4 \times 10^{-4}$ \\
\hline \multirow[t]{3}{*}{ rs6950978 } & 7 & 87200467 & $A$ & T & 0.70 & $A B C B 1$ & Any BMBs & -0.154 & 0.030 & 0.86 & 25,528 & 3,439 & $2.7 \times 10^{-7}$ \\
\hline & & & & & & & Lobar BMBs & -0.153 & 0.037 & 0.86 & 24,101 & 2,101 & $4.1 \times 10^{-5}$ \\
\hline & & & & & & & Mixed BMBs & -0.179 & 0.046 & 0.84 & 23,033 & 1,239 & $1.0 \times 10^{-4}$ \\
\hline \multirow[t]{3}{*}{ rs7533718 } & 1 & 22281393 & A & G & 0.83 & HSPG2 & Any BMBs & -0.140 & 0.042 & 0.87 & 25,402 & 3,412 & $7.5 \times 10^{-4}$ \\
\hline & & & & & & & Lobar BMBs & -0.263 & 0.051 & 0.77 & 22,935 & 2,005 & $2.9 \times 10^{-7}$ \\
\hline & & & & & & & Mixed BMBs & 0.003 & 0.070 & 1.00 & 22,446 & 1,161 & $9.7 \times 10^{-1}$ \\
\hline \multirow[t]{3}{*}{ rs11025317 } & 11 & 3103445 & $A$ & G & 0.12 & OSBPL5 & Any BMBs & 0.172 & 0.049 & 1.19 & 20,330 & 2,918 & $4.3 \times 10^{-4}$ \\
\hline & & & & & & & Lobar BMBs & 0.305 & 0.060 & 1.36 & 18,666 & 1,748 & $3.0 \times 10^{-7}$ \\
\hline & & & & & & & Mixed BMBs & -0.027 & 0.082 & 0.97 & 17,714 & 996 & $7.4 \times 10^{-1}$ \\
\hline \multirow[t]{3}{*}{ rs62522567 } & 8 & 103799094 & A & G & 0.92 & GASAL1 & Any BMBs & -0.231 & 0.051 & 0.79 & 24,118 & 3,115 & $6.9 \times 10^{-6}$ \\
\hline & & & & & & & Lobar BMBs & -0.319 & 0.063 & 0.73 & 22,550 & 1,924 & $4.0 \times 10^{-7}$ \\
\hline & & & & & & & Mixed BMBs & -0.195 & 0.089 & 0.82 & 17,075 & 942 & $2.8 \times 10^{-2}$ \\
\hline \multirow[t]{3}{*}{ rs1058285 } & 19 & 43680051 & $\mathrm{~T}$ & C & 0.61 & PSG5 & Any BMBs & 0.082 & 0.030 & 1.08 & 24,794 & 3,290 & $6.0 \times 10^{-3}$ \\
\hline & & & & & & & Lobar BMBs & 0.188 & 0.038 & 1.21 & 23,535 & 2,021 & $5.3 \times 10^{-7}$ \\
\hline & & & & & & & Mixed BMBs & -0.051 & 0.045 & 0.95 & 22,729 & 1,216 & $2.6 \times 10^{-1}$ \\
\hline \multirow[t]{3}{*}{ rs654240 } & 11 & 69448373 & T & $C$ & 0.41 & CCND1 & Any BMBs & 0.154 & 0.031 & 1.17 & 25,402 & 3,412 & $7.4 \times 10^{-7}$ \\
\hline & & & & & & & Lobar BMBs & 0.116 & 0.039 & 1.12 & 23,528 & 2,080 & $2.8 \times 10^{-3}$ \\
\hline & & & & & & & Mixed BMBs & 0.202 & 0.048 & 1.22 & 23,368 & 1,270 & $3.0 \times 10^{-5}$ \\
\hline
\end{tabular}

Abbreviations: $\mathrm{A} 1$ = effect allele; $\mathrm{A} 2$ = other allele; $\mathrm{Chr}=$ chromosome; $\mathrm{EAF}=$ effect allele frequency; $\mathrm{OR}=$ odds ratio; $\mathrm{SNP}=$ single nucleotide polymorphism . Associations with BMBs with a $p<1 \times 10^{-6}$. If available, the associations of the same genetic variants in the other analyses are also shown.

the $p$ value for significance, dividing 0.05 by the number of single nucleotide polymorphisms (SNPs) tested. Where we had a sufficient number of variants, we assessed the cumulative association of all variants with BMBs using inverse variance weighting across all SNPs, as implemented in the gtx package in R. For WMH, the effect sizes from the largest GWAS sample were used to estimate an overall effect. ${ }^{10}$

\section{Data availability}

The summary statistics will be made available upon publication on the CHARGE dbGaP site under the accession number phs000930.v7.p1 and via the Cerebrovascular Disease Knowledge Portal (cerebrovascularportal.org).

\section{Results}

In the combined CHARGE with additional studies and UK Biobank multiethnic meta-analysis, genetic and BMB rating data were available for 25,862 participants, of whom 3,556 (13.7\%) had BMB. In 2,179 (8.4\%), these were lobar and in $1,293(5.0 \%)$ mixed. The prevalence of any BMB ranged from $6.5 \%$ to $34.3 \%$ for studies using $\mathrm{T}^{*}$-weighted sequences for the assessment of $\mathrm{BMB}$, and from $7.0 \%$ to $36.8 \%$ for studies using SWI sequences. After excluding participants with dementia and stroke, 23,032 individuals remained, of whom 2,889 (12.5\%), $1,843(8.0 \%)$, and 969 (4.2\%) had any, lobar, and mixed BMB, respectively. A complete overview of the included studies is shown in table 1 .

\section{Genome-wide association studies}

A quantile-quantile plot showed mild enrichment of genomewide associations with any BMB (supplementary figure e- 1 , doi.org/10.5061/dryad.mcvdncjz4), and limited genomic inflation was observed $(\lambda=1.02$, LD score regression intercept $=1.02$, supplementary table e-3, doi.org $/ 10.5061 /$ dryad. mcvdncjz4). One locus in the APOE region on chromosome 19 reached genome-wide significance (lead genetic variant 

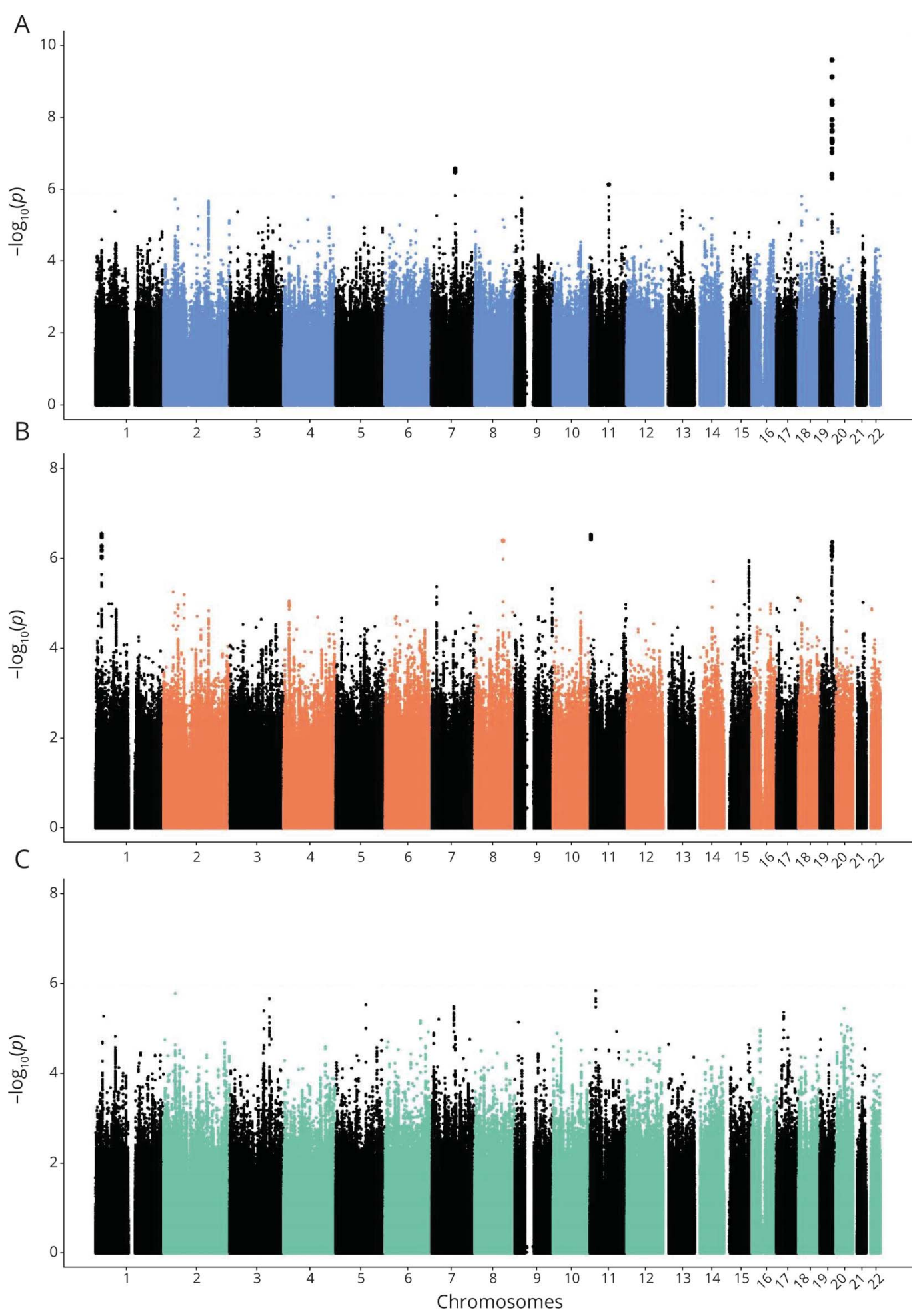

Manhattan plots show genome-wide associations by chromosomal position for (A) any, (B) lobar, and (C) mixed microbleeds.

rs769449; odds ratio [OR] [95\% confidence interval (CI)] $1.33[1.21-1.45] ; p=2.5 \times 10^{-10}$; table 2, figures 1 and 2 , and supplementary figure e-2, doi.org/10.5061/dryad.mcrdncjz4). This effect was stronger for lobar (OR [ $[95 \%$ CI $] 1.32$ [1.19-1.47]; $p=4.3 \times 10^{-7}$ ) than for mixed microbleeds (OR $\left.[95 \% \mathrm{CI}] 1.27[1.11-1.46] ; p=5.4 \times 10^{-4}\right)$, albeit not significantly. Similar associations were observed for the different participating studies (CHARGE with additional studies $I^{2}=$ 0 , $p_{\text {heterozygosity }}=0.68$; CHARGE with additional studies and UK Biobank combined $I^{2}=0$, $p_{\text {heterozygosity }}=0.78$, supplementary figure e-3, doi.org/10.5061/dryad.mcvdncjz4). Functional annotation of the genome-wide significant variants and 
Figure 2 Regional association of genome-wide significant locus for any brain microbleeds

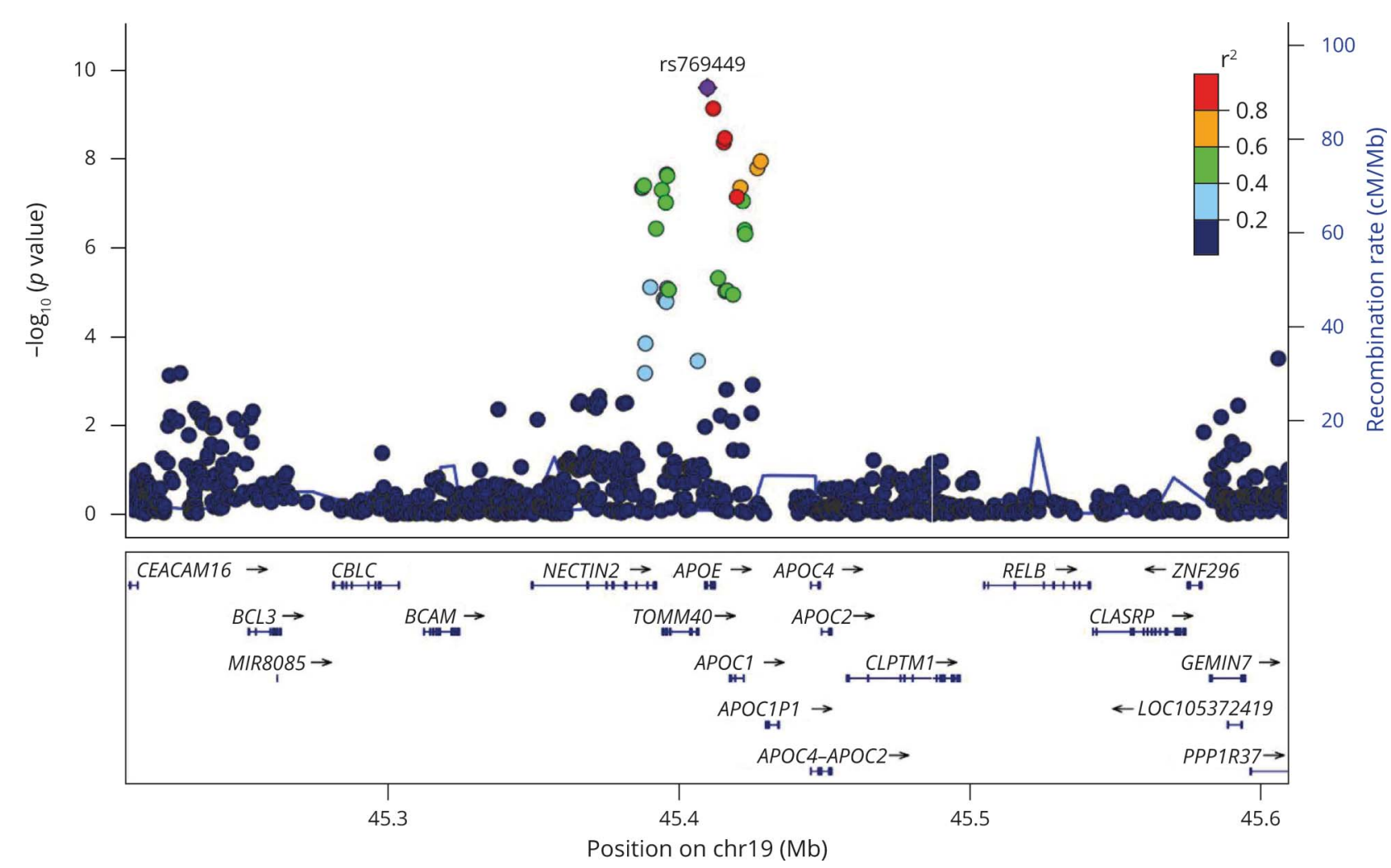

Regional plot shows association of genetic variants in the $A P O E$ region with any brain microbleeds.

genetic variants in $\mathrm{LD}\left(r^{2}>0.8\right)$ are presented in supplementary table e-4, doi.org/10.5061/dryad.mcvdncjz4). In the analysis excluding individuals with dementia and stroke, the effect estimate for the lead SNP rs769449 did not attenuate, although the level of significance slightly decreased, reflecting the smaller sample size (OR [95\% CI] 1.32 [1.20-1.46], $p=2.1$ $\times 10^{-8}$, supplementary table e-5 and supplementary figure e-4, doi.org/10.5061/dryad.mcvdncjz4).

\section{APOE $\varepsilon 2$ and $\varepsilon 4$ count analysis}

To further elucidate whether 1 of the 2 APOE genotypes were driving this identified genetic association between the $A P O E$ region and $\mathrm{BMB}$, we performed a follow-up analysis of this finding, assessing the association of APOE $\varepsilon 2$ and $\varepsilon 4$ allele counts with $\mathrm{BMB}$ in the 2 largest cohorts (Rotterdam Study and UK Biobank). The APOE $\varepsilon 4$ allele count was significantly associated with the number of BMBs (OR [95\% CI] 1.27 [1.14-1.42]; $p=1.3 \times$

Table 3 The effects of $A P O E \varepsilon 2$ and $\varepsilon 4$ allele count on the number of brain microbleeds (BMBs) overall and by location

\begin{tabular}{|c|c|c|c|c|}
\hline Outcome & $\beta$ & SE & OR $(95 \% \mathrm{Cl})$ & $p$ Value \\
\hline \multicolumn{5}{|c|}{$A P O E \varepsilon 2$ allele count } \\
\hline All BMBs & 0.026 & 0.089 & $1.03(0.86-1.22)$ & 0.769 \\
\hline Lobar BMBs & 0.130 & 0.121 & $1.14(0.90-1.44)$ & 0.283 \\
\hline Mixed BMBs & -0.243 & 0.178 & $0.78(0.55-1.11)$ & 0.171 \\
\hline \multicolumn{5}{|c|}{$A P O E \& 4$ allele count } \\
\hline All BMBs & 0.242 & 0.055 & $1.27(1.14-1.42)$ & $1.3 \times 10^{-5}$ \\
\hline Lobar BMBs & 0.285 & 0.069 & $1.33(1.16-1.52)$ & $3.5 \times 10^{-5}$ \\
\hline Mixed BMBs & 0.069 & 0.117 & $1.07(0.85-1.35)$ & 0.553 \\
\hline
\end{tabular}

Abbreviations: $\mathrm{Cl}=$ confidence interval; $\mathrm{OR}=$ odds ratio. 
Table 4 Two-sample mendelian randomization of cardiovascular traits and brain microbleeds overall and by location

\begin{tabular}{|c|c|c|}
\hline Analysis & Estimate $(95 \% \mathrm{CI})$ & $p$ Value \\
\hline \multicolumn{3}{|l|}{ Any brain microbleeds } \\
\hline Type 2 diabetes & $-0.072(-0.176$ to 0.031$)$ & 0.170 \\
\hline Systolic blood pressure & $0.026(0.005$ to 0.046$)$ & $0.013^{a}$ \\
\hline Diastolic blood pressure & 0.046 (0.010 to 0.082$)$ & $0.011^{a}$ \\
\hline Pulse pressure & $0.021(-0.008$ to 0.049$)$ & 0.156 \\
\hline Body mass index & $-0.037(-0.131$ to 0.057$)$ & 0.445 \\
\hline Low density lipoprotein & $0.057(-0.085$ to 0.198$)$ & 0.431 \\
\hline High density lipoprotein & $-0.001(-0.159$ to 0.157$)$ & 0.990 \\
\hline Triglycerides & 0.290 (0.090 to 0.489$)$ & $0.004^{b}$ \\
\hline \multicolumn{3}{|l|}{ Lobar brain microbleeds } \\
\hline Type 2 diabetes & $-0.053(-0.180$ to 0.074$)$ & 0.414 \\
\hline Systolic blood pressure & 0.027 (0.003 to 0.051$)$ & $0.029^{a}$ \\
\hline Diastolic blood pressure & 0.046 (0.003 to 0.088$)$ & $0.035^{a}$ \\
\hline Pulse pressure & $0.023(-0.010$ to 0.057$)$ & 0.174 \\
\hline Body mass index & $-0.023(-0.141$ to 0.094$)$ & 0.697 \\
\hline Low density lipoprotein & $0.145(-0.015$ to 0.306$)$ & 0.076 \\
\hline High density lipoprotein & $-0.024(-0.206$ to 0.159$)$ & 0.799 \\
\hline Triglycerides & $0.250(0.015$ to 0.486$)$ & $0.037^{a}$ \\
\hline \multicolumn{3}{|l|}{ Mixed brain microbleeds } \\
\hline Type 2 diabetes & $-0.074(-0.222$ to 0.073$)$ & 0.323 \\
\hline Systolic blood pressure & $0.024(-0.005$ to 0.054$)$ & 0.108 \\
\hline Diastolic blood pressure & $0.034(-0.019$ to 0.086$)$ & 0.209 \\
\hline Pulse pressure & $0.025(-0.017$ to 0.066$)$ & 0.243 \\
\hline Body mass index & $-0.047(-0.191$ to 0.097$)$ & 0.524 \\
\hline Low density lipoprotein & $-0.078(-0.315$ to 0.159$)$ & 0.519 \\
\hline High density lipoprotein & $-0.050(-0.263$ to 0.162$)$ & 0.642 \\
\hline Triglycerides & 0.374 (0.094 to 0.654$)$ & $0.009^{a}$ \\
\hline
\end{tabular}

Abbreviation: $\mathrm{Cl}=$ confidence interval.

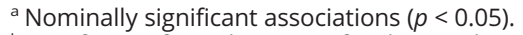

${ }^{\mathrm{b}}$ Significant after adjustment for the number of risk factors ( $p<[0.05 / 8]$ ).

$10^{-5}$; table 3). This effect was stronger for lobar than for mixed microbleeds (OR [95\% CI] 1.33 [1.16-1.52]; $p=$ $3.5 \times 10^{-5}$ and $\mathrm{OR}[95 \% \mathrm{CI}] 1.07[0.85-1.35] ; p=0.553$, respectively). These results did not change after excluding individuals with the APOE $\varepsilon 2 \varepsilon 4$ genotype (supplementary table e-6, doi.org/10.5061/dryad.mcvdncjz4). No significant association was found between the APOE 82 allele count and the number of BMBs (OR [95\% CI] 1.03 [0.86-1.22]; $p=0.769)$, also not after removing individuals with the APOE $\varepsilon 2 \varepsilon 4$ genotype (table 3 and supplementary table e-6, doi.org/10.5061/dryad. mcrdncjz4).

\section{Two-sample mendelian randomization}

Mendelian randomization analyses testing the influence of cardiovascular risk factors on BMBs showed positive nominal associations of systolic blood pressure, diastolic blood pressure, and triglycerides with any BMB and of systolic and diastolic blood pressure and triglycerides with strictly lobar $\mathrm{BMBs}$ as well as triglycerides with deep, infratentorial, or mixed BMBs (table 4). Only the association of triglycerides with any microbleeds survived multiple testing adjustments $(\beta$ $=0.29,95 \%$ CI $0.09-0.49, p=0.004)$; the effect estimate of this association was stronger for mixed microbleeds $(\beta=0.37$, 95\% CI 0.09-0.65, $p=0.009$ ).

\section{Related phenotypes}

One genetic variant previously associated with deep $\mathrm{ICH}$ and $\mathrm{WMH}$ (rs2984613 in the 1q22 locus) was associated with BMB (OR [95\% CI] $1.12[1.05-1.18], p=1.8 \times 10^{-4}$ ), with slightly stronger effects on mixed BMB than lobar BMB (OR [95\% CI] $1.14[1.05-1.25], p=3.2 \times 10^{-3}$ vs OR [95\% CI] 1.09 [1.01-1.17], $p=2.2 \times 10^{-2}$ ) (table 5). One variant known to be associated with lacunar stroke (rs9515201 in the 13q34 locus) also associated with mixed BMB (OR [95\% CI $] 1.12$ [1.02-1.22], $p=0.014)$, but did not associate with lobar BMB (OR [95\% CI] 0.98 [0.91-1.06], $p=0.684$ ). No other CSVD variants were individually associated with $\mathrm{BMB}$. Cumulatively, genetic variants identified for cerebral WMH burden were associated with mixed BMB (OR [95\% CI] 1.78 [1.15-2.77]; $p=$ 0.01 ), but not with lobar BMB (OR [ $[95 \%$ CI $] 1.02$ $[0.71-1.45] ; p=0.93)$. Also, a cumulative effect of previously identified variants for any stroke was found for mixed BMB (OR [95\% CI] 1.78 [1.09-2.91]; $p=0.02$ ), which was similar for variants of any ischemic stroke (OR [95\% CI] 2.00 [1.22-3.27]; $p=0.006)$. Full results of the genetic variants previously identified for $\mathrm{AD}$ and stroke are presented in supplementary table e-7 (doi.org/10.5061/dryad.mcvdncjz4).

\section{Discussion}

We report the first large-scale multiethnic genome-wide study of BMBs in 25,862 individuals, including 3,556 participants with any $\mathrm{BMB}$, of whom 2,179 had strictly lobar and 1,293 mixed $\mathrm{BMB}$. We identified an association with $\mathrm{BMB}$ in the $A P O E$ region, in particular for strictly lobar BMBs, most likely due to risk associated with $A P O E \varepsilon 4$ allele counts.

Our findings are in line with previous studies showing an association between $A P O E \varepsilon 4$ genotypes and $\mathrm{BMB}$, in particular with strictly lobar $\mathrm{BMB} .{ }^{12}$ One genetic variant in $\mathrm{LD}$ with the identified lead SNP (rs769448) is rs429358, which is an $A P O E$ missense variant and 1 of the 2 SNPs constituting $A P O E \varepsilon 2 / 3 / 4$ polymorphisms; this variant was more strongly associated with strictly lobar than mixed BMB. In an 
Table 5 Association of cerebral small vessel disease-associated genetic variants with brain microbleeds (BMBs) overall and by location

\begin{tabular}{|c|c|c|c|c|c|c|c|c|}
\hline \multirow[b]{2}{*}{ Trait } & \multirow[b]{2}{*}{ Locus } & \multirow[b]{2}{*}{ SNP } & \multicolumn{2}{|l|}{ All BMBs } & \multicolumn{2}{|l|}{ Lobar BMBs } & \multicolumn{2}{|l|}{ Mixed BMBs } \\
\hline & & & OR $(95 \% \mathrm{Cl})$ & $p$ Value & OR $(95 \% \mathrm{Cl})$ & $p$ Value & OR $(95 \% \mathrm{Cl})$ & $p$ Value \\
\hline \multirow[t]{2}{*}{ ICH deep } & 1q22 & rs2984613 & $1.12(1.05-1.18)$ & $0.0002^{\mathrm{a}}$ & $1.09(1.01-1.17)$ & $0.022^{a}$ & $1.14(1.05-1.25)$ & $0.003^{a}$ \\
\hline & $13 q 34$ & rs4771674 & $1.03(0.97-1.09)$ & 0.350 & $0.99(0.93-1.07)$ & 0.879 & $1.06(0.97-1.15)$ & 0.218 \\
\hline \multirow[t]{3}{*}{ Lacunar stroke } & $16 q 24$ & rs12445022 & $1.07(1.00-1.13)$ & $0.034^{b}$ & $1.04(0.97-1.12)$ & 0.277 & $1.10(1.00-1.20)$ & $0.039^{b}$ \\
\hline & $10 q 26$ & rs79043147 & $1.02(0.91-1.14)$ & 0.785 & $1.04(0.90-1.21)$ & 0.601 & $1.05(0.87-1.27)$ & 0.582 \\
\hline & $13 q 34$ & rs9515201 & $1.04(0.98-1.10)$ & 0.206 & $0.98(0.91-1.06)$ & 0.684 & $1.12(1.02-1.22)$ & $0.014^{a}$ \\
\hline \multirow[t]{14}{*}{$\mathrm{WMH}^{\mathrm{c}}$} & $2 \mathrm{p} 21$ & rs11679640 & $0.95(0.88-1.01)$ & 0.111 & $0.96(0.88-1.04)$ & 0.300 & $0.98(0.88-1.10)$ & 0.768 \\
\hline & $10 q 24$ & rs12357919 & $1.01(0.94-1.08)$ & 0.881 & $1.00(0.91-1.10)$ & 0.970 & $0.97(0.86-1.09)$ & 0.598 \\
\hline & $6 q 25$ & rs275350 & $1.01(0.95-1.06)$ & 0.775 & $0.98(0.91-1.05)$ & 0.519 & $1.08(0.99-1.17)$ & 0.084 \\
\hline & $1 q 22$ & rs2984613 & $1.12(1.05-1.18)$ & $0.0002^{\mathrm{a}}$ & $1.09(1.01-1.17)$ & $0.022^{b}$ & $1.14(1.05-1.25)$ & $0.003^{a}$ \\
\hline & $17 q 25$ & rs7214628 & $1.00(0.94-1.08)$ & 0.902 & $1.04(0.95-1.13)$ & 0.404 & $1.02(0.91-1.13)$ & 0.779 \\
\hline & $10 q 24$ & rs72848980 & $1.00(0.93-1.08)$ & 0.947 & $1.00(0.91-1.10)$ & 0.970 & $0.98(0.87-1.10)$ & 0.687 \\
\hline & 2q33 & rs72934505 & $1.05(0.96-1.15)$ & 0.264 & $1.01(0.91-1.12)$ & 0.886 & $1.11(0.97-1.27)$ & 0.141 \\
\hline & $2 \mathrm{p} 16$ & rs78857879 & $1.06(0.97-1.17)$ & 0.206 & $1.02(0.91-1.16)$ & 0.695 & $1.08(0.93-1.25)$ & 0.300 \\
\hline & $10 q 24$ & rs7894407 & $1.04(0.98-1.10)$ & 0.212 & $1.01(0.94-1.09)$ & 0.772 & $1.02(0.94-1.12)$ & 0.605 \\
\hline & $10 q 24$ & rs7909791 & $0.99(0.94-1.05)$ & 0.784 & $0.99(0.92-1.06)$ & 0.737 & $0.96(0.88-1.05)$ & 0.420 \\
\hline & $14 q 32$ & rs941898 & $0.95(0.89-1.01)$ & 0.117 & $0.91(0.84-0.99)$ & $0.026^{b}$ & $1.01(0.92-1.12)$ & 0.817 \\
\hline & $13 q 34$ & rs9515201 & $1.04(0.98-1.10)$ & 0.206 & $0.98(0.91-1.06)$ & 0.684 & $1.12(1.02-1.22)$ & $0.014^{b}$ \\
\hline & $17 q 21$ & rs962888 & $1.02(0.96-1.08)$ & 0.570 & $1.01(0.93-1.09)$ & 0.868 & $1.02(0.93-1.12)$ & 0.641 \\
\hline & & Overall & $1.29(0.97-1.72)$ & 0.074 & $1.02(0.71-1.45)$ & 0.927 & $1.78(1.15-2.77)$ & $0.010^{b}$ \\
\hline \multicolumn{9}{|c|}{$\begin{array}{l}\text { Abbreviations: } \mathrm{Cl}=\text { confidence interval; } \mathrm{ICH}=\text { intracerebral hemorrhage; } \mathrm{OR}=\text { odds ratio; SNP = single nucleotide polymorphism; WMH = white matter } \\
\text { hyperintensities. } \\
\text { ORs aligned to risk allele from original studies. } \\
\text { a Significant after Bonferroni correction ( } p<0.05 / \text { number of genetic variants). } \\
\text { b Nominally significant }(p<0.05) \text {. } \\
\text { c In the overall score for } \mathrm{WMH} \text {, rs } 12357919 \text { was left out because this genetic variant was in linkage disequilibrium }\left(r^{2}>0.2\right) \text { with rs } 72848980 \text {. }\end{array}$} \\
\hline
\end{tabular}

additional analysis performed in a subset of the cohorts, we confirmed the known link between APOE $\varepsilon 4$ allele count and the number of BMBs, with stronger effect estimates for the strictly lobar BMB subtype compared to the mixed subtype. This association was less pronounced and nonsignificant for the APOE $\varepsilon 2$ allele count, which is also in accordance with previous studies, ${ }^{12}$ although this might be due to a lack of power. Other studies did find a significant association between APOE $\varepsilon 2$ alleles and cerebral angiopathy-related $\mathrm{ICH},{ }^{9}$ with stronger estimates for the lobar compared to the deep phenotype, which is similar to our study. Stronger effects for ICH in the previous study than for BMBs in the current study might be due to sampling variability or biological differences between the 2 traits. The APOE locus remained significant with a similar effect estimate in the GWAS meta-analysis performed in a dementia- and stroke-free sample, indicating that this association was not driven by individuals with disease, and suggesting that $A P O E$ may already affect $\mathrm{BMB}$ risk in a preclinical phase of dementia or stroke.

Our findings further suggest that higher triglyceride levels may be causally related to the presence of BMBs. This relationship between the genetics of triglycerides and $\mathrm{BMBs}$, in particular for mixed BMBs, confirms other studies showing a contribution of cardiovascular risk factors to $\mathrm{BMB}$ risk, mainly for deep or infratentorial BMBs. ${ }^{6}$ A previous 2-sample mendelian randomization study did not find a significant association between the genetics of triglycerides and $\mathrm{ICH}$, although the direction of effect for the triglycerides analysis was the same as for BMBs in the current study. ${ }^{44}$ However, this positive link between the genetics of triglyceride levels and the presence of BMBs is in contrast with previous phenotypic association studies showing an inverse relationship between triglyceride levels and BMB risk in elderly population-based individuals. ${ }^{45,46}$ Similarly, lower triglyceride levels have been associated with an increased ICH risk. ${ }^{45,47,48}$ 
Thus, our finding should be interpreted with caution and further studies are needed to elucidate the exact causal mechanisms underlying lipid profiles over time and BMB risk.

We also showed that genetic variation previously associated with risk of CSVD (i.e., WMH burden, lacunar infarcts, and subcortical $\mathrm{ICH}$ ) are associated with an increased risk of $\mathrm{BMB}$, and that this association is restricted to mixed rather than lobar $\mathrm{BMB}$. This suggests that mixed BMBs have a shared pathophysiologic pathway with other features of the CSVD spectrum. This is consistent with recent data showing genetic sharing between WMH, lacunar infarcts, and subcortical $\mathrm{ICH}^{49}$ Increasing evidence suggests that small vessel arteriopathy may lead to $\mathrm{WMH}$, acute lacunar infarction, and $\mathrm{ICH}{ }^{50}$ Our data suggest that mixed BMBs are likely to be related to the same underlying arterial pathology.

Associations of the APOE \&4 genotype with decreased cognitive function in the elderly are well-established. ${ }^{51}$ Although part of this decline is due to the predisposition to $\mathrm{AD}$ pathology conferred by $A P O E \varepsilon 4$, our results suggest that another part might be due to vascular mechanisms predisposing to BMBs, most likely via cerebral amyloid angiopathy. Apart from the $A P O E$ locus, no enrichment of previously reported genetic variants for $\mathrm{AD}$ was found. This is in line with a previously published WMH GWAS, in which no significant association was found between the identified loci for $\mathrm{WMH}$ and $\mathrm{AD} .{ }^{11} \mathrm{It}$ might indicate that $A P O E$ is mainly responsible for the genetic overlap between $\mathrm{BMB}$ and $\mathrm{AD}$. Alternatively, the current $\mathrm{BMB}$ and $A D$ GWAS could be underpowered to identify biological pathways playing a role in the development of CSVD subsequently leading to $\mathrm{AD}$. As another possibility, environmental factors might primarily play a role in the link between $\mathrm{BMB}$ and neurodegenerative diseases later in life. Although the $19 q 13$ locus was the only significant BMB locus, we did observe a cumulative effect of stroke SNPs on mixed BMB, suggestive of overlapping biological mechanisms underlying the two.

In this study, we were able to collate most of the GWAS data available worldwide on BMBs, enabling us to perform by far the largest GWAS meta-analysis of BMB to date. Our study also has limitations. Despite being the largest study to date, the number of individuals with BMB was still modest, resulting in a limited power to identify genetic factors related to BMB. Significantly larger sample sizes are needed to fully elucidate the genetic contribution to $\mathrm{BMB}$. Because of the relatively small number of participants with BMBs, we combined the presence of deep, infratentorial, and mixed BMBs into one group of mixed BMBs, even though previous research has suggested there may be differences between strictly deep and mixed BMBs. ${ }^{20}$ With larger sample sizes, it would be interesting to investigate whether there are differences in the genetics between deep and infratentorial BMBs. The percentage of individuals with microbleeds varied across studies, which may be due to a true difference in the presence of BMBs or population differences, e.g., age distributions, ethnicities, and lifestyle factors. However, the differences in the presence of BMBs might also be partially attributable to different sensitivities of the used methodologies, e.g., the magnetic field strength of the MRI scanner or the sequence used for rating BMB. Another limitation of the current study is the large majority of individuals of European ancestry included in the analyses; previous studies have shown differences in the occurrence, distribution, and associated risks of BMBs across different ethnicities. ${ }^{52-54}$ Therefore, it would be valuable for future studies to increase the sample size of individuals of non-European ancestry in order to be able to perform ancestry-specific analyses. Also, larger reference panels would enable us to investigate rare genetic variants as well. Lastly, it may be worthwhile to take into account the number of microbleeds instead of treating the phenotype as a dichotomous trait, which results in a loss of information.

We identified genetic variants located in the APOE region associated with $\mathrm{BMB}$, which were more strongly associated with lobar than mixed BMB. Our data also demonstrated genetic overlap between mixed $\mathrm{BMB}$ and other features of CSVD, emphasizing that they represent part of the CSVD spectrum.

\section{Study funding}

This study was funded by the European Union's Horizon 2020 Framework Programme for Research and Innovation (grant 347 agreement 667375, CoSTREAM). Information regarding funding and acknowledgements for individual cohorts is provided in the Supplementary information (doi.org/10.5061/dryad.mcvdncjz4).

\section{Disclosure}

This study was not industry sponsored. M.J. Knol, D. Lu, and M. Traylor report no disclosures relevant to the manuscript. H.H.H. Adams is supported by ZonMW grant 916.19.151. J.R.J. Romero, A.V. Smith, M. Fornage, E. Hofer, and J. Liu report no disclosures relevant to the manuscript. I.C. Hostettler received funding from the Alzheimer Research UK and Dunhill Medical Trust Foundation. M. Luciano, S. Trompet, A.-K. Giese, S. Hilal, E.B. van den Akker, D. Vojinovic, S. Li, S. Sigurdsson, S.J. van der Lee, and C.R. Jack, Jr. report no disclosures relevant to the manuscript. D. Wilson received funding from the Stroke Foundation/British Heart Foundation. P. Yilmaz, C.L. Satizabal, D.C.M. Liewald, J. van der Grond, C. Chen, Y. Saba, A. van der Lugt, M.E. Bastin, B.G. Windham, C.Y. Cheng, L. Pirpamer, K. Kantarci, J.J. Himali, Q. Yang, Z. Morris, A.S. Beiser, D.J. Tozer, M.W. Vernooij, N. Amin, M. Beekman, J.Y. Koh, and D.J. Stott report no disclosures relevant to the manuscript. $H$. Houlden received funding from the Alzheimer Research UK and Dunhill Medical Trust Foundation. R. Schmidt, R.F. Gottesman, and A.D. MacKinnon report no disclosures relevant to the manuscript. C. DeCarli is supported by the Alzheimer's Disease Center (P30 AG 010129) and serves as a consultant of Novartis Pharmaceuticals. V. Gudnason, I.J. Deary, C.M. van Duijn, P.E. Slagboom, T.Y. Wong, and N.S. Rost report no disclosures relevant to the manuscript. J.W. Jukema is an Established Clinical Investigator of the Netherlands Heart Foundation (grant 2001 D 032). T.H. Mosley reports no disclosures relevant to the manuscript. D.J. Werring received 
funding from the Stroke Foundation/British Heart Foundation. H. Schmidt, J.M. Wardlaw, M.A. Ikram, S. Seshadri, L.J. Launer, and H.S. Markus report no disclosures relevant to the manuscript. Go to Neurology.org/N for full disclosures.

\section{Publication history}

Received by Neurology December 16, 2019. Accepted in final form August 3, 2020.

\section{Appendix Authors}

\begin{tabular}{|c|c|c|}
\hline Name & Location & Contribution \\
\hline $\begin{array}{l}\text { Maria J. Knol, } \\
\text { BSc }\end{array}$ & $\begin{array}{l}\text { Erasmus MC University } \\
\text { Medical Center, Rotterdam, } \\
\text { the Netherlands }\end{array}$ & $\begin{array}{l}\text { Performed statistical } \\
\text { analysis, drafted the } \\
\text { manuscript }\end{array}$ \\
\hline $\begin{array}{l}\text { Dongwei Lu, } \\
\text { MD, PhD }\end{array}$ & University of Cambridge, UK & Acquired data \\
\hline $\begin{array}{l}\text { Matthew } \\
\text { Traylor, PhD }\end{array}$ & University of Cambridge, UK & $\begin{array}{l}\text { Performed statistical } \\
\text { analysis, drafted the } \\
\text { manuscript }\end{array}$ \\
\hline $\begin{array}{l}\text { Hieab H.H. } \\
\text { Adams, MD, } \\
\text { PhD }\end{array}$ & $\begin{array}{l}\text { Erasmus MC University } \\
\text { Medical Center, Rotterdam, } \\
\text { the Netherlands }\end{array}$ & $\begin{array}{l}\text { Performed statistical } \\
\text { analysis, acquired data, } \\
\text { drafted the manuscript }\end{array}$ \\
\hline $\begin{array}{l}\text { José Rafael J. } \\
\text { Romero, MD }\end{array}$ & Boston University, MA & Acquired data \\
\hline $\begin{array}{l}\text { Albert V. } \\
\text { Smith, PhD }\end{array}$ & University of Michigan & $\begin{array}{l}\text { Performed statistical } \\
\text { analysis }\end{array}$ \\
\hline $\begin{array}{l}\text { Myriam } \\
\text { Fornage, PhD }\end{array}$ & University of Texas, Houston & $\begin{array}{l}\text { Performed statistical } \\
\text { analysis }\end{array}$ \\
\hline $\begin{array}{l}\text { Edith Hofer, } \\
\text { PhD }\end{array}$ & $\begin{array}{l}\text { Medical University of Graz, } \\
\text { Austria }\end{array}$ & $\begin{array}{l}\text { Performed statistical } \\
\text { analysis }\end{array}$ \\
\hline $\begin{array}{l}\text { Junfeng Liu, } \\
\text { MD, PhD }\end{array}$ & University of Cambridge, UK & Acquired data \\
\hline $\begin{array}{l}\text { Isabel C. } \\
\text { Hostettler, } \\
\text { MD }\end{array}$ & $\begin{array}{l}\text { University College London, } \\
\text { UK }\end{array}$ & $\begin{array}{l}\text { Performed statistical } \\
\text { analysis, acquired data }\end{array}$ \\
\hline $\begin{array}{l}\text { Michelle } \\
\text { Luciano, PhD }\end{array}$ & University of Edinburgh, UK & $\begin{array}{l}\text { Performed statistical } \\
\text { analysis }\end{array}$ \\
\hline $\begin{array}{l}\text { Stella } \\
\text { Trompet, } \\
\text { PhD }\end{array}$ & $\begin{array}{l}\text { Leiden University Medical } \\
\text { Center, the Netherlands }\end{array}$ & $\begin{array}{l}\text { Performed statistical } \\
\text { analysis }\end{array}$ \\
\hline $\begin{array}{l}\text { Anne-Katrin } \\
\text { Giese, MD }\end{array}$ & $\begin{array}{l}\text { Massachusetts General } \\
\text { Hospital, Boston }\end{array}$ & $\begin{array}{l}\text { Performed statistical } \\
\text { analysis }\end{array}$ \\
\hline $\begin{array}{l}\text { Saima Hilal, } \\
\text { MD, PhD }\end{array}$ & $\begin{array}{l}\text { Memory Aging and Cognition } \\
\text { Center, Singapore }\end{array}$ & $\begin{array}{l}\text { Performed statistical } \\
\text { analysis, acquired data }\end{array}$ \\
\hline $\begin{array}{l}\text { Erik B. van } \\
\text { den Akker, } \\
\text { PhD }\end{array}$ & $\begin{array}{l}\text { Leiden University Medical } \\
\text { Center, the Netherlands }\end{array}$ & $\begin{array}{l}\text { Performed statistical } \\
\text { analysis }\end{array}$ \\
\hline $\begin{array}{l}\text { Dina } \\
\text { Vojinovic, } \\
\text { MD, PhD }\end{array}$ & $\begin{array}{l}\text { Erasmus MC University } \\
\text { Medical Center, Rotterdam, } \\
\text { the Netherlands }\end{array}$ & $\begin{array}{l}\text { Performed statistical } \\
\text { analysis }\end{array}$ \\
\hline Shuo Li, PhD & Boston University, MA & $\begin{array}{l}\text { Performed statistical } \\
\text { analysis }\end{array}$ \\
\hline
\end{tabular}

Appendix (continued)

\begin{tabular}{|c|c|c|}
\hline Name & Location & Contribution \\
\hline $\begin{array}{l}\text { Sigurdur } \\
\text { Sigurdsson, } \\
\text { MSc }\end{array}$ & $\begin{array}{l}\text { Icelandic Heart Association, } \\
\text { Kopavogur, Iceland }\end{array}$ & Acquired data \\
\hline $\begin{array}{l}\text { Sven J. van } \\
\text { der Lee, MD, } \\
\text { PhD }\end{array}$ & $\begin{array}{l}\text { Erasmus MC University } \\
\text { Medical Center, Rotterdam, } \\
\text { the Netherlands }\end{array}$ & $\begin{array}{l}\text { Performed statistical } \\
\text { analysis }\end{array}$ \\
\hline $\begin{array}{l}\text { Clifford R. } \\
\text { Jack, Jr., MD }\end{array}$ & Mayo Clinic, Rochester, MN & Acquired data \\
\hline $\begin{array}{l}\text { Duncan } \\
\text { Wilson, PhD }\end{array}$ & $\begin{array}{l}\text { University College London, } \\
\text { UK }\end{array}$ & Acquired data \\
\hline $\begin{array}{l}\text { Pinar Yilmaz, } \\
\text { MD }\end{array}$ & $\begin{array}{l}\text { Erasmus MC University } \\
\text { Medical Center, Rotterdam, } \\
\text { the Netherlands }\end{array}$ & Acquired data \\
\hline $\begin{array}{l}\text { Claudia L. } \\
\text { Satizabal, } \\
\text { PhD }\end{array}$ & UT Health San Antonio & $\begin{array}{l}\text { Performed statistical } \\
\text { analysis }\end{array}$ \\
\hline $\begin{array}{l}\text { David C.M. } \\
\text { Liewald, BSc }\end{array}$ & University of Edinburgh, UK & Acquired data \\
\hline $\begin{array}{l}\text { Jeroen van } \\
\text { der Grond, } \\
\text { PhD }\end{array}$ & $\begin{array}{l}\text { Leiden University Medical } \\
\text { Center, the Netherlands }\end{array}$ & Acquired data \\
\hline $\begin{array}{l}\text { Christopher } \\
\text { Chen, FRCP }\end{array}$ & $\begin{array}{l}\text { Memory Aging and Cognition } \\
\text { Center, Singapore }\end{array}$ & Acquired data \\
\hline $\begin{array}{l}\text { Yasaman } \\
\text { Saba, MSc }\end{array}$ & $\begin{array}{l}\text { Medical University of Graz, } \\
\text { Austria }\end{array}$ & $\begin{array}{l}\text { Performed statistical } \\
\text { analysis }\end{array}$ \\
\hline $\begin{array}{l}\text { Aad van der } \\
\text { Lugt, MD, } \\
\text { PhD }\end{array}$ & $\begin{array}{l}\text { Erasmus MC University } \\
\text { Medical Center, Rotterdam, } \\
\text { the Netherlands }\end{array}$ & Acquired data \\
\hline $\begin{array}{l}\text { Mark E. } \\
\text { Bastin, PhD }\end{array}$ & University of Edinburgh, UK & Acquired data \\
\hline $\begin{array}{l}\text { B. Gwen } \\
\text { Windham, } \\
\text { MD }\end{array}$ & $\begin{array}{l}\text { University of Mississippi } \\
\text { Medical Center, Jackson }\end{array}$ & Acquired data \\
\hline $\begin{array}{l}\text { Ching-Yu } \\
\text { Cheng, MD, } \\
\text { PhD }\end{array}$ & $\begin{array}{l}\text { Singapore Eye Research } \\
\text { Institute }\end{array}$ & Acquired data \\
\hline $\begin{array}{l}\text { Lukas } \\
\text { Pirpamer, } \\
\text { MSc }\end{array}$ & $\begin{array}{l}\text { Medical University of Graz, } \\
\text { Austria }\end{array}$ & Acquired data \\
\hline $\begin{array}{l}\text { Kejal } \\
\text { Kantarci, MD }\end{array}$ & Mayo Clinic, Rochester, MN & Acquired data \\
\hline $\begin{array}{l}\text { Jayandra J. } \\
\text { Himali, PhD }\end{array}$ & Boston University, MA & $\begin{array}{l}\text { Performed statistical } \\
\text { analysis }\end{array}$ \\
\hline $\begin{array}{l}\text { Qiong Yang, } \\
\text { PhD }\end{array}$ & Boston University, MA & Acquired data \\
\hline $\begin{array}{l}\text { Zoe Morris, } \\
\text { MD }\end{array}$ & University of Edinburgh, UK & Acquired data \\
\hline $\begin{array}{l}\text { Alexa S. } \\
\text { Beiser, PhD }\end{array}$ & Boston University, MA & Acquired data \\
\hline $\begin{array}{l}\text { Daniel J. } \\
\text { Tozer, PhD }\end{array}$ & University of Cambridge, UK & Acquired data \\
\hline
\end{tabular}

Continued 
Appendix (continued)

\begin{tabular}{|c|c|c|}
\hline Name & Location & Contribution \\
\hline $\begin{array}{l}\text { Meike W. } \\
\text { Vernooij, MD, } \\
\text { PhD }\end{array}$ & $\begin{array}{l}\text { Erasmus MC University } \\
\text { Medical Center, Rotterdam, } \\
\text { the Netherlands }\end{array}$ & Acquired data \\
\hline $\begin{array}{l}\text { Najaf Amin, } \\
\text { PhD }\end{array}$ & $\begin{array}{l}\text { Erasmus MC University } \\
\text { Medical Center, Rotterdam, } \\
\text { the Netherlands }\end{array}$ & Acquired data \\
\hline $\begin{array}{l}\text { Marian } \\
\text { Beekman, } \\
\text { PhD }\end{array}$ & $\begin{array}{l}\text { Leiden University Medical } \\
\text { Center, the Netherlands }\end{array}$ & Acquired data \\
\hline $\begin{array}{l}\text { Jia Yu Koh, } \\
\text { PhD }\end{array}$ & $\begin{array}{l}\text { Singapore Eye Research } \\
\text { Institute }\end{array}$ & $\begin{array}{l}\text { Performed statistical } \\
\text { analysis, acquired data }\end{array}$ \\
\hline $\begin{array}{l}\text { David J. Stott, } \\
\text { MD, PhD }\end{array}$ & University of Glasgow, UK & Acquired data \\
\hline $\begin{array}{l}\text { Henry } \\
\text { Houlden, } \\
\text { PhD }\end{array}$ & $\begin{array}{l}\text { University College London, } \\
\text { UK }\end{array}$ & Acquired data \\
\hline $\begin{array}{l}\text { Reinhold } \\
\text { Schmidt, MD }\end{array}$ & $\begin{array}{l}\text { Medical University of Graz, } \\
\text { Austria }\end{array}$ & Acquired data \\
\hline $\begin{array}{l}\text { Rebecca F. } \\
\text { Gottesman, } \\
\text { MD, PhD }\end{array}$ & $\begin{array}{l}\text { Johns Hopkins University, } \\
\text { Baltimore, MD }\end{array}$ & Acquired data \\
\hline $\begin{array}{l}\text { Andrew D. } \\
\text { MacKinnon, } \\
\text { MD }\end{array}$ & $\begin{array}{l}\text { Atkinson Morley } \\
\text { Neurosciences Centre, } \\
\text { London, UK }\end{array}$ & Acquired data \\
\hline $\begin{array}{l}\text { Charles } \\
\text { DeCarli, MD }\end{array}$ & Boston University, MA & Acquired data \\
\hline $\begin{array}{l}\text { Vilmundur } \\
\text { Gudnason, } \\
\text { MD, PhD }\end{array}$ & $\begin{array}{l}\text { Icelandic Heart Association, } \\
\text { Kopavogur, Iceland }\end{array}$ & Acquired data \\
\hline $\begin{array}{l}\text { lan J. Deary, } \\
\text { PhD }\end{array}$ & University of Edinburgh, UK & Acquired data \\
\hline $\begin{array}{l}\text { Cornelia M. } \\
\text { van Duijn, } \\
\text { PhD }\end{array}$ & $\begin{array}{l}\text { Erasmus MC University } \\
\text { Medical Center, Rotterdam, } \\
\text { the Netherlands }\end{array}$ & Acquired data \\
\hline $\begin{array}{l}\text { P. Eline } \\
\text { Slagboom, } \\
\text { PhD }\end{array}$ & $\begin{array}{l}\text { Leiden University Medical } \\
\text { Center, the Netherlands }\end{array}$ & Acquired data \\
\hline $\begin{array}{l}\text { Tien Yin } \\
\text { Wong, MD, } \\
\text { PhD }\end{array}$ & $\begin{array}{l}\text { Singapore Eye Research } \\
\text { Institute }\end{array}$ & Acquired data \\
\hline $\begin{array}{l}\text { Natalia S. } \\
\text { Rost, MD, } \\
\text { MPH }\end{array}$ & $\begin{array}{l}\text { Massachusetts General } \\
\text { Hospital, Boston }\end{array}$ & Acquired data \\
\hline $\begin{array}{l}\text { J. Wouter } \\
\text { Jukema, PhD }\end{array}$ & $\begin{array}{l}\text { Leiden University Medical } \\
\text { Center, Leiden, the } \\
\text { Netherlands }\end{array}$ & Acquired data \\
\hline $\begin{array}{l}\text { Thomas H. } \\
\text { Mosley, PhD }\end{array}$ & $\begin{array}{l}\text { University of Mississippi } \\
\text { Medical Center, Jackson }\end{array}$ & Acquired data \\
\hline $\begin{array}{l}\text { David J. } \\
\text { Werring, PhD }\end{array}$ & $\begin{array}{l}\text { University College London, } \\
\text { UK }\end{array}$ & Acquired data \\
\hline $\begin{array}{l}\text { Helena } \\
\text { Schmidt, MD, } \\
\text { PhD }\end{array}$ & $\begin{array}{l}\text { Medical University of Graz, } \\
\text { Austria }\end{array}$ & Acquired data \\
\hline $\begin{array}{l}\text { Joanna M. } \\
\text { Wardlaw, MD }\end{array}$ & University of Edinburgh, UK & Acquired data \\
\hline
\end{tabular}

Appendix (continued)

\begin{tabular}{|c|c|c|}
\hline Name & Location & Contribution \\
\hline $\begin{array}{l}\text { M. Arfan } \\
\text { Ikram, MD, } \\
\text { PhD }\end{array}$ & $\begin{array}{l}\text { Erasmus MC University } \\
\text { Medical Center, Rotterdam, } \\
\text { the Netherlands }\end{array}$ & $\begin{array}{l}\text { Acquired data, directed } \\
\text { the work }\end{array}$ \\
\hline $\begin{array}{l}\text { Sudha } \\
\text { Seshadri, MD }\end{array}$ & $\begin{array}{l}\text { UT Health San Antonio, San } \\
\text { Antonio }\end{array}$ & $\begin{array}{l}\text { Acquired data, directed } \\
\text { the work }\end{array}$ \\
\hline $\begin{array}{l}\text { Lenore J. } \\
\text { Launer, PhD }\end{array}$ & $\begin{array}{l}\text { National Institutes of Health, } \\
\text { Baltimore, MD }\end{array}$ & $\begin{array}{l}\text { Acquired data, directed } \\
\text { the work }\end{array}$ \\
\hline $\begin{array}{l}\text { Hugh S. } \\
\text { Markus, DM, } \\
\text { FMed Sci }\end{array}$ & University of Cambridge, UK & $\begin{array}{l}\text { Acquired data, drafted } \\
\text { the manuscript, } \\
\text { directed the work }\end{array}$ \\
\hline
\end{tabular}

Appendix 2 Coinvestigators

Coinvestigators are listed at links.Iww.com/WNL/B222

\section{References}

1. Wardlaw JM, Smith EE, Biessels GJ, et al. Neuroimaging standards for research into small vessel disease and its contribution to ageing and neurodegeneration. Lancet Neurol 2013;12:822-838

2. Poels MM, Vernooij MW, Ikram MA, et al. Prevalence and risk factors of cerebral microbleeds: an update of the Rotterdam Scan Study. Stroke 2010;41:S103-S106.

3. Debette S, Schilling S, Duperron MG, Larsson SC, Markus HS. Clinical significance of magnetic resonance imaging markers of vascular brain injury: a systematic review and meta-analysis. JAMA Neurol 2019;76:81-94.

4. Wilson D, Ambler G, Lee KJ, et al. Cerebral microbleeds and stroke risk after ischaemic stroke or transient ischaemic attack: a pooled analysis of individual patient data from cohort studies. Lancet Neurol 2019;18:653-665.

5. Wang Z, Soo YO, Mok VC. Cerebral microbleeds: is antithrombotic therapy safe to administer? Stroke 2014;45:2811-2817.

6. Vernooij MW, van der Lugt A, Ikram MA, et al. Prevalence and risk factors of cerebral microbleeds: the Rotterdam Scan Study. Neurology 2008;70:1208-1214.

7. van Rooden S, van der Grond J, van den Boom R, et al. Descriptive analysis of the Boston criteria applied to a Dutch-type cerebral amyloid angiopathy population. Stroke 2009;40:3022-3027.

8. Akoudad S, Portegies ML, Koudstaal PJ, et al. Cerebral microbleeds are associated with an increased risk of stroke: the Rotterdam Study. Circulation 2015;132: 509-516.

9. Biffi A, Sonni A, Anderson CD, et al. Variants at APOE influence risk of deep and lobar intracerebral hemorrhage. Ann Neurol 2010;68:934-943.

10. Traylor M, Tozer DJ, Croall ID, et al. Genetic variation in PLEKHG1 is associated with white matter hyperintensities $(\mathrm{n}=11,226)$. Neurology 2019;92:e749-e757.

11. Verhaaren BF, Debette S, Bis JC, et al. Multiethnic genome-wide association study of cerebral white matter hyperintensities on MRI. Circ Cardiovasc Genet 2015;8:398-409.

12. Maxwell SS, Jackson CA, Paternoster L, et al. Genetic associations with brain microbleeds: systematic review and meta-analyses. Neurology 2011;77:158-167.

13. Li HQ Cai WJ, Hou XH, et al. Genome-wide association study of cerebral microbleeds on MRI. Neurotox Res 2020;37:146-155.

14. Psaty BM, O'Donnell CJ, Gudnason V, et al. Cohorts for Heart and Aging Research in Genomic Epidemiology (CHARGE) Consortium: design of prospective metaanalyses of genome-wide association studies from 5 cohorts. Circ Cardiovasc Genet 2009;2:73-80.

15. Traylor M, Zhang CR, Adib-Samii P, et al. Genome-wide meta-analysis of cerebral white matter hyperintensities in patients with stroke. Neurology 2016;86:146-153.

16. Greenberg SM, Vernooij MW, Cordonnier C, et al. Cerebral microbleeds: a guide to detection and interpretation. Lancet Neurol 2009;8:165-174.

17. Nandigam RN, Viswanathan A, Delgado P, et al. MR imaging detection of cerebral microbleeds: effect of susceptibility-weighted imaging, section thickness, and field strength. AJNR Am J Neuroradiol 2009;30:338-343.

18. Cheng AL, Batool S, McCreary CR, et al. Susceptibility-weighted imaging is more reliable than $\mathrm{T}^{*}$-weighted gradient-recalled echo MRI for detecting microbleeds. Stroke 2013;44:2782-2786.

19. Goos JD, van der Flier WM, Knol DL, et al. Clinical relevance of improved microbleed detection by susceptibility-weighted magnetic resonance imaging. Stroke 2011;42: 1894-1900.

20. Ding J, Sigurethsson S, Jonsson PV, et al. Space and location of cerebral microbleeds, cognitive decline, and dementia in the community. Neurology 2017;88:2089-2097. 
21. Kantarci K, Gunter JL, Tosakulwong N, et al. Focal hemosiderin deposits and betaamyloid load in the ADNI cohort. Alzheimers Dement 2013;9:S116-S123.

22. Qiu C, Cotch MF, Sigurdsson S, et al. Retinal and cerebral microvascular signs and diabetes: the Age, Gene/Environment Susceptibility-Reykjavik Study. Diabetes 2008;57:1645-1650.

23. Roob G, Lechner A, Schmidt R, Flooh E, Hartung HP, Fazekas F. Frequency and location of microbleeds in patients with primary intracerebral hemorrhage. Stroke 2000;31:2665-2669.

24. Graff-Radford J, Simino J, Kantarci K, et al. Neuroimaging correlates of cerebral microbleeds: the ARIC Study (Atherosclerosis Risk in Communities). Stroke 2017; 48:2964-2972.

25. Wilson D, Ambler G, Shakeshaft C, et al. Cerebral microbleeds and intracranial haemorrhage risk in patients anticoagulated for atrial fibrillation after acute ischaemic stroke or transient ischaemic attack (CROMIS-2): a multicentre observational cohort study. Lancet Neurol 2018;17:539-547.

26. Cordonnier C, Potter GM, Jackson CA, et al. Improving interrater agreement about brain microbleeds: development of the Brain Observer MicroBleed Scale (BOMBS). Stroke 2009;40:94-99.

27. Romero JR, Preis SR, Beiser A, et al. Risk factors, stroke prevention treatments, and prevalence of cerebral microbleeds in the Framingham Heart Study. Stroke 2014;45: 1492-1494.

28. Wardlaw JM, Bastin ME, Valdes Hernandez MC, et al. Brain aging, cognition in youth and old age and vascular disease in the Lothian Birth Cohort 1936: rationale, design and methodology of the imaging protocol. Int J Stroke 2011;6:547-559.

29. Altmann-Schneider I, van der Grond J, Slagboom PE, et al. Lower susceptibility to cerebral small vessel disease in human familial longevity: the Leiden Longevity Study. Stroke 2013;44:9-14.

30. Altmann-Schneider I, Trompet S, de Craen AJ, et al. Cerebral microbleeds are predictive of mortality in the elderly. Stroke 2011;42:638-644.

31. Willer CJ, Li Y, Abecasis GR. METAL: fast and efficient meta-analysis of genomewide association scans. Bioinformatics 2010;26:2190-2191.

32. Bulik-Sullivan BK, Loh PR, Finucane HK, et al. LD Score regression distinguishes confounding from polygenicity in genome-wide association studies. Nat Genet 2015;47:291-295.

33. Ward LD, Kellis M. HaploReg: a resource for exploring chromatin states, conservation, and regulatory motif alterations within sets of genetically linked variants. Nucleic Acids Res 2012;40:D930-D934.

34. Xue A, Wu Y, Zhu Z, et al. Genome-wide association analyses identify 143 risk variants and putative regulatory mechanisms for type 2 diabetes. Nat Commun 2018;9:2941.

35. Warren HR, Evangelou E, Cabrera CP, et al. Genome-wide association analysis identifies novel blood pressure loci and offers biological insights into cardiovascular risk. Nat Genet 2017;49:403.

36. Yengo L, Sidorenko J, Kemper KE, et al. Meta-analysis of genome-wide association studies for height and body mass index in approximately 700000 individuals of European ancestry. Hum Mol Genet 2018;27:3641-3649.
37. Surakka I, Horikoshi M, Magi R, et al. The impact of low-frequency and rare variants on lipid levels. Nat Genet 2015;47:589-597.

38. Traylor M, Malik R, Nalls MA, et al. Genetic variation at $16 \mathrm{q} 24.2$ is associated with small vessel stroke. Ann Neurol 2017;81:383-394.

39. Rannikmäe K, Sivakumaran V, Millar H, et al. COL4A2 is associated with lacunar ischemic stroke and deep ICH: meta-analyses among 21,500 cases and 40,600 controls. Neurology 2017;89:1829-1839.

40. Woo D, Falcone GJ, Devan WJ, et al. Meta-analysis of genome-wide association studies identifies $1 \mathrm{q} 22$ as a susceptibility locus for intracerebral hemorrhage. Am J Hum Genet 2014;94:511-521.

41. Malik R, Chauhan G, Traylor M, et al. Multiancestry genome-wide association study of 520,000 subjects identifies 32 loci associated with stroke and stroke subtypes. Nat Genet 2018;50:524-537.

42. Malik R, Rannikmae K, Traylor M, et al. Genome-wide meta-analysis identifies 3 novel loci associated with stroke. Ann Neurol 2018;84:934-939.

43. Jansen IE, Savage JE, Watanabe K, et al. Genome-wide meta-analysis identifies new loci and functional pathways influencing Alzheimer's disease risk. Nat Genet 2019;51:404-413.

44. Georgakis MK, Malik R, Anderson CD, Parhofer KG, Hopewell JC, Dichgans M. Genetic determinants of blood lipids and cerebral small vessel disease: role of highdensity lipoprotein cholesterol. Brain 2020;143:597-610.

45. Wieberdink RG, Poels MM, Vernooij MW, et al. Serum lipid levels and the risk of intracerebral hemorrhage: the Rotterdam Study. Arterioscler Thromb Vasc Biol 2011; 31:2982-2989.

46. Ding J, Sigurdsson S, Garcia M, et al. Risk factors associated with incident cerebral microbleeds according to location in older people: the Age, Gene/Environment Susceptibility (AGES)-Reykjavik Study. JAMA Neurol 2015;72:682-688.

47. Bonaventure A, Kurth T, Pico F, et al. Triglycerides and risk of hemorrhagic stroke vs. ischemic vascular events: the Three-City Study. Atherosclerosis 2010;210:243-248.

48. Sturgeon JD, Folsom AR, Longstreth WT Jr, Shahar E, Rosamond WD, Cushman M. Risk factors for intracerebral hemorrhage in a pooled prospective study. Stroke 2007; 38:2718-2725.

49. Traylor M, Rutten-Jacobs LC, Thijs V, et al. Genetic associations with white matter hyperintensities confer risk of lacunar stroke. Stroke 2016;47:1174-1179.

50. Chung J, Marini S, Pera J, et al. Genome-wide association study of cerebral small vessel disease reveals established and novel loci. Brain 2019;142:3176-3189.

51. Caselli RJ, Reiman EM, Osborne D, et al. Longitudinal changes in cognition and behavior in asymptomatic carriers of the APOE e4 allele. Neurology 2004;62:1990-1995.

52. Charidimou A, Kakar P, Fox Z, Werring DJ. Cerebral microbleeds and recurrent stroke risk: systematic review and meta-analysis of prospective ischemic stroke and transient ischemic attack cohorts. Stroke 2013;44:995-1001.

53. Copenhaver BR, Hsia AW, Merino JG, et al. Racial differences in microbleed prevalence in primary intracerebral hemorrhage. Neurology 2008;71:1176-1182.

54. Kakar P, Charidimou A, Werring DJ. Cerebral microbleeds: a new dilemma in stroke medicine. JRSM Cardiovasc Dis 2012;1:2048004012474754. 


\section{Neurology}

\section{Association of common genetic variants with brain microbleeds: A genome-wide association study \\ Maria J. Knol, Dongwei Lu, Matthew Traylor, et al.}

Neurology 2020;95;e3331-e3343 Published Online before print September 10, 2020

DOI 10.1212/WNL.0000000000010852

This information is current as of September 10, 2020

\section{Updated Information \&} Services

References

Citations

Subspecialty Collections

Permissions \& Licensing

Reprints including high resolution figures, can be found at: http://n.neurology.org/content/95/24/e3331.full

This article cites 54 articles, 28 of which you can access for free at: http://n.neurology.org/content/95/24/e3331.full\#ref-list-1

This article has been cited by 1 HighWire-hosted articles: http://n.neurology.org/content/95/24/e3331.full\#\#otherarticles

This article, along with others on similar topics, appears in the following collection(s):

Association studies in genetics

http://n.neurology.org/cgi/collection/association_studies_in_genetics MRI

http://n.neurology.org/cgi/collection/mri

Other cerebrovascular disease/ Stroke

http://n.neurology.org/cgi/collection/other_cerebrovascular_disease_s troke

Information about reproducing this article in parts (figures,tables) or in its entirety can be found online at:

http://www.neurology.org/about/about_the_journal\#permissions

Information about ordering reprints can be found online:

http://n.neurology.org/subscribers/advertise

Neurology ${ }^{\circledR}$ is the official journal of the American Academy of Neurology. Published continuously since 1951, it is now a weekly with 48 issues per year. Copyright Copyright ( 2020 The Author(s). Published by Wolters Kluwer Health, Inc. on behalf of the American Academy of Neurology.. All rights reserved. Print ISSN: 0028-3878. Online ISSN: 1526-632X.

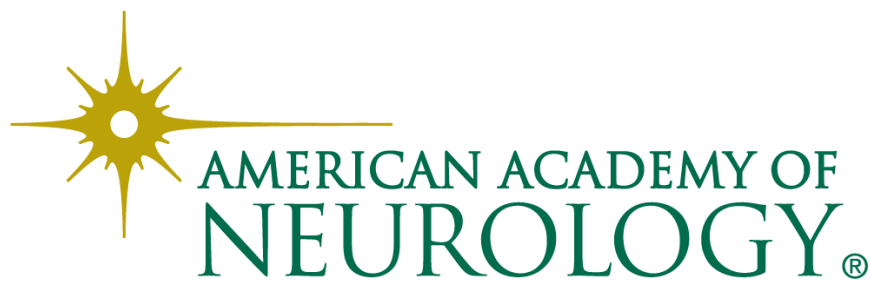

